\title{
Industrial processing of canned beans
}

\section{Vanderleia Schoeninger ${ }^{1}$ Silvia Renata Machado Coelho ${ }^{2}$ Priscila Zaczuk Bassinello ${ }^{3}$}

\footnotetext{
${ }^{1}$ Universidade Federal da Grande Dourados (UFGD), Faculdade de Ciências Agrárias (FCA), 79804-970, Dourados, MS, Brasil. E-mail: vanderleia_sch@yahoo.com.br. Corresponding author.

${ }^{2}$ Programa de Pós-graduação em Engenharia Agrícola, Universidade Estadual do Oeste do Paraná (UNIOESTE), 85819-110, Cascavel, PR, Brasil.

${ }^{3}$ Empresa Brasileira de Pesquisa Agropecuária, Embrapa Arroz e Feijão, Santo Antônio de Goiás, GO, Brasil.
}

\begin{abstract}
Beans are popular as a protein-filled legume of high nutritional value, being one of the most planted species in the world. However, recent years have seen a decrease in the consumption of beans, owing to the time necessary to cook it domestically. Thus, it is being replaced in people's diets by other foods. An alternative preparation that supplies modern consumers' demands is industrially processed beans. This article aimed to provide a literature review on the processing of canned beans. Few recent studies have been performed in Brazil on this subject, as most studies have focused instead on the technological quality of dry bean grains processing. In this article industrial processing concepts and features, production unit operations, and canned beans quality standards will be discussed. These efforts are expected to contribute to the Brazilian beans production chain, and consequently to increase consumption of canned beans and the demand for industrial processing of beans in both the domestic market and future product exports.
\end{abstract}

Key words: Phaseolus vulgaris L., canning, hydration, blanching.

Revisão: processamento industrial do feijão tipo enlatado

RESUMO: O feijão destaca-se no cenário mundial como uma leguminosa rica em proteínas e com alto valor nutricional, sendo estando entre uma das espécies mais cultivadas em todo o mundo. Porém, observa-se diminuição do consumo deste alimento devido à demanda de tempo no seu preparo doméstico, sendo então substituido na dieta. Uma alternativa que atende as demandas do consumidor moderno é o processamento industrial. O objetivo deste trabalho é fornecer uma revisão de literatura abordando informações sobre o processamento tipo enlatado em feijão. Atualmente, no Brasil, são realizados poucos trabalhos dentro desta linha de pesquisa, visto que o maior enfoque é para a qualidade tecnológica dos grãos para o consumo tradicional, na forma seca. Neste material são apresentadas informações sobre alguns conceitos e detalhes do processamento industrial, das operações unitárias na produção e dos parâmetros de qualidade avaliados no feijão enlatado. Espera-se, contribuir com a cadeia produtiva do feijão brasileiro, aumentando o consumo e as demandas do processamento industrial, tanto em mercado interno quanto para futuras exportações do produto.

Palavras-chave: Phaseolus vulgaris L., enlatamento, hidratação, branqueamento.

\section{INTRODUCTION}

Dry legumes are used worldwide, and especially in developing countries, as an inexpensive source of protein and calories. After soy (Glycine Max), the common bean (Phaseolus vulgaris L.) is the most important legume, featuring high levels of protein, starch, fibers, vitamins, and minerals. Beans have nutritional and culinary properties desirable for dry, in natura grain consumers, and processing industries (OSORIO-DÍAZ et al., 2002; RONDINI et al., 2013; ZAMINDAR et al., 2013; LIMA et al., 2014).
Owing to the need for more adequate alternatives to fulfill the demands of bean consumers in Brazil and other countries, adding value to the food via industrial processing and offering semi-prepared foods of high nutritional quality, sensory value and reduced cooking times is necessary.

PAN et al., (2010) suggested that preprocessing beans may bring benefits such as the increase in product value and greater profitability for farmers and food manufacturers. Different types of beans, such as dehydrated, precooked, canned, microwave oven-ready, flakes, frozen and refrigerated, are in high demand in the food industry, 
particularly among fast-food restaurants, schools, and domestic consumers (UEBERSAX, 2006). One of the main forms of processed beans reported in the market are cooked and canned beans, a very common form in developed countries throughout Europe and North America. In this type of processing, beans are usually prepared by hydration operations, grain blanching in hot water, canning, brine addition, and addition of other components such as tomato sauce, pork meat or flavor additives, followed by hermetic canning and thermal processing. Canned beans have simple characteristics with wide acceptance in the international market (UEBERSAX, 2006).

Therefore, this study provided a literature review on the industrial processing of canned beans. Not many studies have been carried out recently in Brazil within this line of research, as most studies have chosen to focus instead on the quality of dry bean grains processing technology for traditional consumption, that is, dry form. This study aimed to provide information to academia and the Brazilian canned beans transformation industry with a view to improve studies in this line of research.

\section{Canned-type processing}

According to SIDDIQ \& UEBERSAX (2013), there are several ways of adding value to beans through processing, especially canning and precooked products such as dehydrated, frozen, and extruded beans, flours, and protein concentrates. Canned beans are a convenient alternative in the food market since they are more easily prepared (ZANOVEC et al., 2011) in comparison with dry beans, which take considerable time in cooking (BASSINELLO, 2008).

With the increase in professional, social and financial demands on families and the reduction in the amount of available time for cooking, food choices are increasingly based on cost, taste, convenience, quality and cooking time (ZANOVEC et al., 2001; WANDER $\&$ FERREIRA, 2011). Therefore, canned beans are an attractive alternative for many consumers since they are quickly and easily prepared.

The canning of foods such as beans aims to preserve the product, inhibiting chemical changes, enzymatic alterations, and microbial development. In the $20^{\text {th }}$ century, the processing industry of canned foods expanded in the United States, Australia, and Europe, where commercial standards for products and processing techniques were defined (MISHRA \& SINHA, 2011). With regard to consumption, canned beans are a widely accepted product worldwide. In the United States, while there are several varieties available in the dry form, approximately $60 \%$ of beans production is canned (ZANOVEC et al., 2011).

In Brazil, this product is not as popular because most consumers buy the grains in the dry form. Nevertheless, within the last decade different brands and packages have appeared in the supermarket aisles, making it possible for consumers to try processed beans. ALMEIDA et al. (2012) conducted research on the consumption of canned beans in a city in southern Brazil, Cascavel-PR, where they determined that only $4.0 \%$ of the population acquire and consume beans in the dry form. The following section discusses the peculiarities of the industrial processing of beans, and the quality evaluations of the finished product.

\section{Canned beans processing stages}

Typical canned beans industrial processing can be described in the following stages: cleaning and classification of grains, hydration, manual or electronic classification after hydration, blanching, packaging, addition of sauce or brine, seaming of cans, thermal processing, freezing and labeling (Figure 1) (WHITE \& HOWARD, 2013). However, in some industrial plants these stages may follow a different sequence according to the type of product and the adopted processing, as it can be observed in table 1 . In the following section, some characteristics of the most common operations in the thermal processing of canned beans are discussed.

\section{Cleaning and classification}

The industrial process starts with cleaning and classification of the raw material by cleaning machines that use sets of sieves and air to remove foreign materials and other vegetable species. Furthermore, electronic visual inspection systems are used for the removal of broken, discolored grains, and non-standard-sized beans.

\section{Hydration}

In the second stage of the processing, mashing or hydration of bean grains occurs. This aims to promote cotyledon grain hydration by passing water through capillaries reported in the integument and hilum. As a result, the grains soften so that they can be cooked. On average, the water content reported in beans grains before processing ranges from $12 \%$ to $16 \%$. The mashing process aims to obtain grains of approximately $53 \%$ to $57 \%$ water content (WHITE \& HOWARD, 2013).

The ratio of grain mass to water volume used in hydration process varies in accordance with 


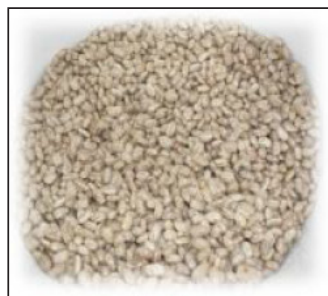

(a)

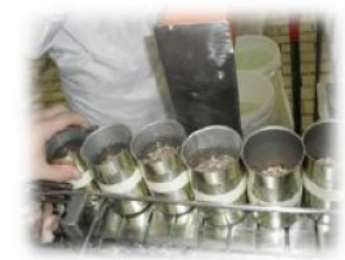

(b)

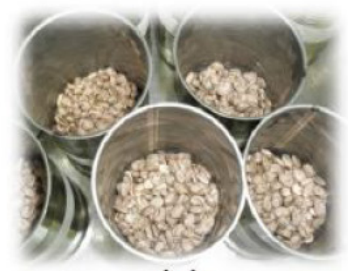

(c)

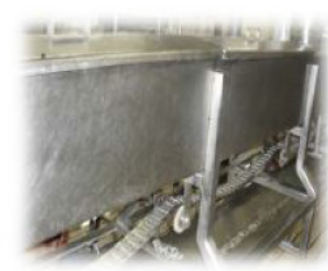

(d)

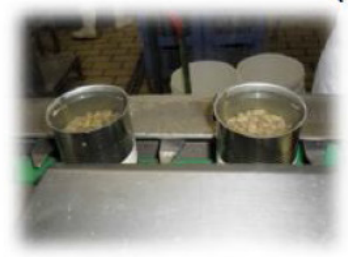

(e)

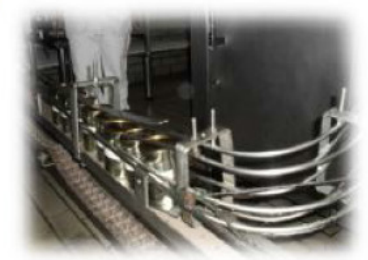

(f)

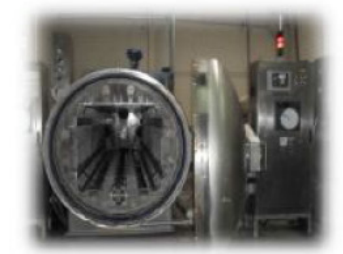

(g)

Figure 1 - Some of the stages of the beans industrial processing: (a) grain cleaning and selection, (b) and (c) accommodation of the product and brine in the package, (d) oxygen exhaustion tunnel inside packages (e) filling up with brine and making enough room for headspace (f) seaming and (g) cooking and sterilization in an autoclave.

the process that the industry employs, but in general, $1 / 3$ is most commonly used ratio. Grains are kept in stainless steel tanks, at room temperature conditions for a period of time that ranges from 8-16h. The time needed is inversely proportional to the initial amount of water in bean grains. However, the process is modified in relation to the hydration time. During the hydration stage of the canned beans processing, WALTERS et al. (1997) and POSA-MACALINCAG et al. (2002) allowed beans to stay at room temperature conditions for a maximum of $30 \mathrm{~min}$. According to ZAMINDAR et al. (2013), extended periods of time may be harmful, favoring microbial proliferation.

The temperature used in hydration is also a factor that may alter the process. On average, low temperatures $\left(10^{\circ} \mathrm{C}\right.$ to $\left.35^{\circ} \mathrm{C}\right)$ do not significantly affect the water percentage absorbed by the grains (WHITE \& HOWARD, 2013). However, in high temperature hydration conditions (from about $40^{\circ} \mathrm{C}$ to $60^{\circ} \mathrm{C}$ ), an increase in the hydration level and reduction in time for the beans reach the hydration peak is observed. This indicates a balance in the diffusion process (ABU-GHANNAM \& McKENNA, 1997; ZIMMERMANN et al., 2009).

In the Brazilian industry, there are some peculiarities in the hydration stage. It is done at room temperature conditions for a $10-\mathrm{h}$ period, using product mass and water volume of $1 / 1.3$, and the process is carried out in two stages. Halfway through hydration time, at the end of five hours, water is removed from the tank, and a new volume of clean water is added, which remains until the end of the process. However, other processors do not use hydration in grains (Figure 1); the product is directly conditioned in the package, it receives the brine, and it is finally sent for thermal processing.

Another important aspect is the quality of the water used in hydration. The amount of calcium ions $\left(\mathrm{Ca}^{++}\right)$in the water influences the absorption and bean grains' texture significantly. A low concentration of calcium softens grains, whereas a high concentration causes resistance to softening (WHITE \& HOWARD, 2013). Calcium is an additive used in canned beans processing as it contributes to the increase of the final product firmness, which is something demanded by the consumers market. The effect of calcium ion on texture is due to the hardening of the integument and cell wall cotyledons by the formation of $\mathrm{Ca}^{++}$complexes and pectin (BALASUBRAMANIAN et al., 2000). Other additives are also pointed out by MATELLA et al. (2013) such as ethylenediaminetetraacetic acid (EDTA) in a concentration of approximately $0.01 \%$, which enables the formation of chelates with calcium ions and crosslinking with pectin, which contributes to product firmness. Another additive that is mentioned is sodium bicarbonate $\left(\mathrm{NaHCO}_{3}\right)$ at the concentration of 0.1 to $2 \%$ with the function of increasing the hydration water $\mathrm{pH}$ and; consequently, the absorption level. The industry generally applies a calcium concentration of $0.025 \mathrm{~mol} \mathrm{~L}^{-1}$ calcium (POSA-MACALINCAG et al., 2002). 
Table 1 - Features of unit operations applied on the industrial processing of some kinds of beans of the Phaseolus vulgaris L. species.

\begin{tabular}{|c|c|c|}
\hline Type of bean & 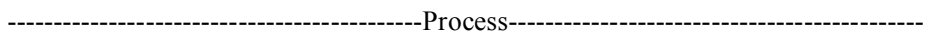 & References \\
\hline Navy bean & $\begin{array}{l}\text { Hydration in } \mathrm{Ca}++ \text { solution }(100 \mathrm{ppm}) \text { in two stages: } 30 \mathrm{~min} \text { at } 21^{\circ} \mathrm{C} \text { and } 30 \mathrm{~min} \\
\text { at } 87^{\circ} \mathrm{C} \text {. The blanching operation was not used. Cooking and sterilization for } \\
45 \mathrm{~min} \text { at } 116^{\circ} \mathrm{C} \text { and } 10.4 \times 10^{4} \mathrm{~Pa} \text { pressure. }\end{array}$ & Walters et al. (1997) \\
\hline Kidney bean & $\begin{array}{l}\text { Hydration at } 21^{\circ} \mathrm{C} \text { for } 30 \mathrm{~min} \text {. After blanching at } 88^{\circ} \mathrm{C} \text { for } 30 \mathrm{~min} \text { followed by } \\
\text { cooling in cold water for } 5 \mathrm{~min} \text {. Addition of brine at } 90^{\circ} \mathrm{C} \text { and air exhaustion } \\
\text { from the packages for } 5 \mathrm{~min} \text {. Rotating autoclave cooking for } 45 \mathrm{~min} \text { at } 116^{\circ} \mathrm{C} \text { and } \\
1.04 \times 10^{5} \mathrm{~Pa} \text {. Cooling at } 22^{\circ} \mathrm{C} \text { for } 15 \mathrm{~min} \text {. }\end{array}$ & $\begin{array}{l}\text { Posa-Macalincag et al. } \\
\qquad(2002)\end{array}$ \\
\hline Small white beans & $\begin{array}{c}\text { Hydration during } 18 \mathrm{~h} \text { in water at room temperature, blanching for } 8 \mathrm{~min} \text { at } 85^{\circ} \mathrm{C} \text {, } \\
\text { and thermal processing for } 32 \mathrm{~min} \text { at } 127^{\circ} \mathrm{C} \text {. }\end{array}$ & Merwe et al. (2006) \\
\hline Barlotti and Kidney beans & $\begin{array}{l}\text { Hydration in water at } 22^{\circ} \mathrm{C} \text { for } 16 \mathrm{~h} \text {. The blanching operation was not used. } \\
\text { Cooking at high pressure and } 120^{\circ} \mathrm{C} \text { for } 15 \mathrm{~min} .\end{array}$ & Guzel \& Sayar (2012) \\
\hline Black beans & $\begin{array}{l}\text { Hydration in water at room temperature for } 30 \mathrm{~min} \text { without blanching. Addition } \\
\text { of brine comprised of } \mathrm{NaCl} \text {, sucrose and } \mathrm{CaCl} 2 \text {. Cooking at } 116^{\circ} \mathrm{C} \text { for } 45 \mathrm{~min} \\
\text { and cooling at } 38^{\circ} \mathrm{C} \text {. }\end{array}$ & Cichy et al. (2014) \\
\hline White beans & $\begin{array}{l}\text { Hydration for } 12-14 \mathrm{~h} \text { followed by blanching at } 70^{\circ} \mathrm{C} \text { for } 9 \mathrm{~min} \text {. Addition of } \\
\text { NaCl-based brine and ascorbic acid. Cooking time was } 42 \mathrm{~min} \text { at } 116^{\circ} \mathrm{C} \text { and } \\
\text { cooling at } 38^{\circ} \mathrm{C} \text { during } 35 \mathrm{~min} \text {. }\end{array}$ & Pedrosa et al. (2015) \\
\hline
\end{tabular}

After the mashing stage, the grains are sent to a new classification, which may be done manually or with the aid of electronic classifiers. This is done in order to remove grains that are broken during hydration or have had their integument broken, and to remove foreign material that may have remained in the grain mass after the cleaning stage. WHITE \& HOWARD (2013) point out the use of separation systems by density and fluctuation, which differentiate the hydrated grain from other materials in the process.

\section{Blanching}

After the removal of damaged grains and other foreign materials in the hydration stage, the next step in industrial processing is blanching. This process consists of a thermal treatment that applies high temperatures with a short-time exposure for the grains. According to YUCEL et al. (2010), blanching of legumes and vegetables is a pre-treatment method that aims to deactivate enzymes and remove gases from the surface and intercellular spaces, thus preventing oxidation and discoloring of the product on the shelf. It has the added benefit of reducing the amount of pathogenic and harmful microorganisms in the food as well. Furthermore, this stage also prewarms the product before it receives sauce or brine, which is the content of the package that is at a high temperature (MISHRA \& SINHA, 2011; MATELLA et al., 2013). Among the canned beans processing stages, blanching generates significant amounts of agro-industrial waste, which is an effluent that is rich in organic matter that must be treated adequately before being disposed of in water bodies (MISHRA \& SINHA, 2011).

There are many commercial blanching processes in the industry, and they depend on the kind of grain and the cultivation technique employed. A typical beans blanching process immerses the grains in water between $82^{\circ} \mathrm{C}$ and $93^{\circ} \mathrm{C}$, and the beans are kept at that temperature for three to eight minutes (MATELLA et al., 2013). Nevertheless, there are some differences in the process. SLUPSKI (2012) used blanching in a water/product ratio of $1 / 5$, a temperature between $96^{\circ} \mathrm{C}$ and $98^{\circ} \mathrm{C}$ for three minutes, which was followed by cooling in cold water for $30 \mathrm{~min}$. WALTERS et al., (1997) and POSA-MACALINCAG et al. (2002) used water at $87^{\circ} \mathrm{C}-88^{\circ} \mathrm{C}$ for $30 \mathrm{~min}$ for blanching without the cooling stage, which promoted good hydration and minimum damage in the grains. In the Brazilian processing industry, blanching stage uses water in temperature range of $70^{\circ} \mathrm{C}$ to $90^{\circ} \mathrm{C}$ for $2 \mathrm{~min}$, and the cooling is generally not carried out.

\section{Packaging}

Blanching process is followed by conditioning the product in packages. The most used processed beans packages are aluminum cans, which is a safe material that guarantees protection and product preservation. There are several sizes for these packages, but the most typical sizes for the previously mentioned processes, i.e. extended-time mashing at room temperature (without warming) and blanching at high temperature for a short period of time, are $198-227 \mathrm{~g}, 255-312 \mathrm{~g}, 396-454 \mathrm{~g}$, and 1,446-1,729g 
(WHITE \& HOWARD, 2013). The Brazilian industry generally uses aluminum packages with a capacity of 300-380g, and Tetra Recart packages with a capacity of $340-380 \mathrm{~g}$.

With regard to packages, the research, development, and marketing departments of processers have invested much in giving a modern and practical appearance to the product, and consequently attracting more consumers. Other packages for processed beans have appeared such as autoclavable Recart, developed by Tetra $\mathrm{Pak}^{\circledR}$, which is a carton package resistant to high temperature and steam pressure in the cooking system (WHITE \& HOWARD, 2013). Another innovative package is the stand-up pouch type, which has an aluminum base attached to polypropylene. It is heat resistant, allowing consumers to warm up the product in a microwave oven. Such innovative packages have been gaining ground in the industry because of their convenience, cost, and environmental advantages (MISHRA \& SINHA, 2011).

\section{Sauce addition}

After storing the grains in the package, the sauce or brine is added in the following proportion: approximately $52 \%$ of the capacity of the package is filled with beans and $48 \%$ with sauce or brine (WHITE \& HOWARD, 2013). There is a great variation in the composition of sauces and brines used in processed beans. However, basic brine formulas comprise a combination of $1.8-3.0 \%(\mathrm{~m} / \mathrm{v})$ of sodium chloride $(\mathrm{NaCl})$, and $3.6-5.4 \%(\mathrm{~m} / \mathrm{v})$ of sugar. In brine, chemical components such as EDTA and calcium chloride $\left(\mathrm{CaCl}_{2}\right)$ are also added to increase firmness and reduce the product coloration loss in the case of cultivars of the colors group (WHANG \& CHANG, 1988). The effect on coloration is explained by the action of chelation of the iron ion, which therefore reduces the oxidation of canned beans and alteration of color in the final product (MATELLA et al., 2013).

Other products may also be added, such as brine with garlic, onions, pepper, tomato sauce, beef or pork meat, and sweet sauces. Many recipes in the processing industry bring out a different taste depending on the market's regional demand. The brine or sauce temperature during filling must be close to the white grains temperature, that is, approximately $82^{\circ} \mathrm{C}-93^{\circ} \mathrm{C}$, which fixes the vacuum when closing the package (SIDDIQ et al., 2011). Another important aspect is not completely filling up the package. A onecentimeter space, known as headspace, must remain free of the product at the top of the can (WANG \& CHANG, 1988). This space prevents imperfections in the package such as expansion of the beans during cooking, and allows complete sterilization (MISHRA \& SINHA, 2011).

\section{Thermal processing}

Thermal processing is also a key stage in the industrialization of beans processing because this is the stage where cooking and sterilization of the product occurs, thus deactivating the microorganisms and guaranteeing alimentary safety. This stage is carried out in a hermetic device known as industrial autoclave, which applies liquid water, steam water or a mixture of these two in its operation, providing heat transfer to the inside of the product. The packages coming out of the seaming machine are conditioned in the autoclave, and then closed. The temperature of the process ranges between $110^{\circ} \mathrm{C}-135^{\circ} \mathrm{C}$, which may depend on the heating environment, and the applied pressure is typically $1.04 \times 10^{5} \mathrm{~Pa}$, that is, $1.06 \mathrm{kgf} \mathrm{cm}^{-2}$ (WALTERS et al., 1997; POSA-MACALING et al., 2002; MISHRA \& SINHA, 2011; MATELLA et al., 2013).

The necessary time for cooking and sterilization of the product is influenced by some factors such as the resistance of microorganisms or enzymes to heat, heating conditions, food $\mathrm{pH}$, and packaging used (FELLOWS, 2006). Regarding the thermal resistance of microorganisms, two parameters should be considered: the values $\mathrm{D}$ and $\mathrm{Z}$. Value $\mathrm{D}$ stands for the time necessary for the destruction of $90 \%$ of the population of a microorganism at a certain temperature; therefore, reducing the population of a microorganism to a tenth of the initial one. Value $\mathrm{Z}$ stands for the number of degrees centigrade to which the temperature should be increased in the process to make deterioration time ten times shorter.

The heating mediums used may be water or steam, which varies the heating temperature because of its thermodynamic properties. Beans $\mathrm{pH}$ is nonacidic, that is, it is greater than 4.5. In this range, the most harmful spore-forming microorganism that is resistant to heat is Clostridium botulinum, which may produce the botulinum toxin, and its elimination is a minimal requirement for sterilization (FELLOWS, 2006; SPOTO, 2006; MISHRA \& SINHA, 2011; WHITE \& HOWARD, 2013). Regarding the packaging, heat penetration up to the center of the package is greater when the package size is small. The material also influences the heat penetration level because of the thermal conductivity, which is faster in metal than in glass or plastic.

With regard to the kind of autoclave, there are different work mechanisms. The most used model 
in beans processing is the static autoclave, in which the medium is pressurized by steam water, with which it is constantly supplied during the cooking process. Rotating autoclaves are also used; in this kind of device, packages are shaken, which results in greater heat transfer to the product and reduced processing time. A third kind of device is the continuous autoclave. Packages are transported through the device, and the conveyor belt sometimes shakes using direct a flame with a high temperature for the cooking and sterilization process (MISHRA \& SINHA, 2011).

\section{Cooling, labeling and stocking}

After thermal treatment, packages are cooled down with water at a temperature ranging from $30^{\circ} \mathrm{C}-40^{\circ} \mathrm{C}$, which prevents deterioration due to thermophilic bacteria. Furthermore, the use of cooling prevents the deformation and strain in the seamed parts of the package (WHITE \& HOWARD, 2013). The identification of the batch with the date of processing and validity is completed after the package is cooled. In some industrial plants, identification labeling is done prior to cooking. In these cases, the data are printed in a black ink that during cooking and sterilization is altered, becoming bluish. This color change indicates that the sterilization process was completed correctly.

Product storage at room temperature conditions and further commercial distribution are next. WALTERS et al. (1997) and POSAMACALINCAG et al. (2002) suggest that quality and microbiological analyses can carried out two weeks after the beginning of storage.

\section{Canned beans quality parameters}

The quality of canned beans has many aspects, including physical, chemical, nutritional, and sensory characteristics. Physical and sensory characteristics are evaluated first, followed by some chemical parameters of the product. To ensure a high quality of canned beans, quality raw material is necessary. Characteristics like size, new beans appearance, coloration, and a low amount of damage are essential for obtaining a quality product at the end of the process (KELLY \& CICHY, 2013).

The main physical characteristics assessed during processing are water absorption, hydration coefficient, and damage level after hydration. In the final product, the following parameters are assessed: vacuum measurement, headspace height, gross weight measurement, drained weight, net weight, percentage by weight of the drained product, visual appearance and grains size, texture, damage level, agglutination, and color of the drained grains and broth (HOSFIELD et al., 1984; MERWE et al., 2006a; MERWE et al., 2006b;WHITE \& HOWARD, 2013).

Water absorption is measured at the end of the grains hydration stage by measuring the product mass. Having this value and the initial product mass allows for calculation of the hydration coefficient (HC), which relates the hydrated grains to dry grains. Coefficients ranging from 1.8 to 2.0 are considered optimum by the industry and indicate good hydration (BALASUBRAMANIAN et al., 2000).

In the final product, the vacuum maintenance is evaluated in the package through perforation of the top by a vacuometer device. After that, the package is opened, and the headspace height is measured with the help of a graduated ruler. The gross weight is reported by measuring the can mass with the product. Later, the grains are drained for two minutes onto an 8 -mesh sieve $(0.239 \mathrm{~cm})$ that is placed at a $20^{\circ}$-angle. Subsequently, the drained mass is measured. The percentage of drained weight may be calculated with this weight according to MERWE et al. (2006a), which relates the drained product mass to the total content of the package $(\mathrm{g})$.

Trained judges, who assess the presence of integuments, product integrality, grain size-uniformity and coloration, and broth consistency and coloration, and verify the visual appearance. This assessment is crucial in maintaining the quality parameters, and it is a reference for the industry to verify its process and offer a product that satisfies consumer preference (POSA-MACALINCAG et al., 2002; WHITE \& HOWARD, 2013). The appearance of different Brazilian beans cultivars of the most consumed commercial classes, carioca and black beans, are shown in figure 2. MERWE et al. (2006a) suggested that a grade of 10 can be attributed to a sample that has intact grains and no loosened integuments. Beans should be of uniform size and coloration, and be shiny and luminous; grade 1 is attributed to samples that display broken grains, loosened integuments, opaque color, and dense, opaque broth. The degree of agglutination of the product is measured by visual assessment and grading that varies on a scale from 1 to 3 . The grade 1 is attributed to beans samples that display high agglutination in the bottom of the can, and the grade 3 is attributed to beans samples that display loosened, non-agglutinated grains (BALASUBRAMANIAN et al., 1999).

The color of grains and broth must also be assessed because it is appreciated characteristic by the consumer. Many factors alter the coloration of the product during processing such as degradation of 


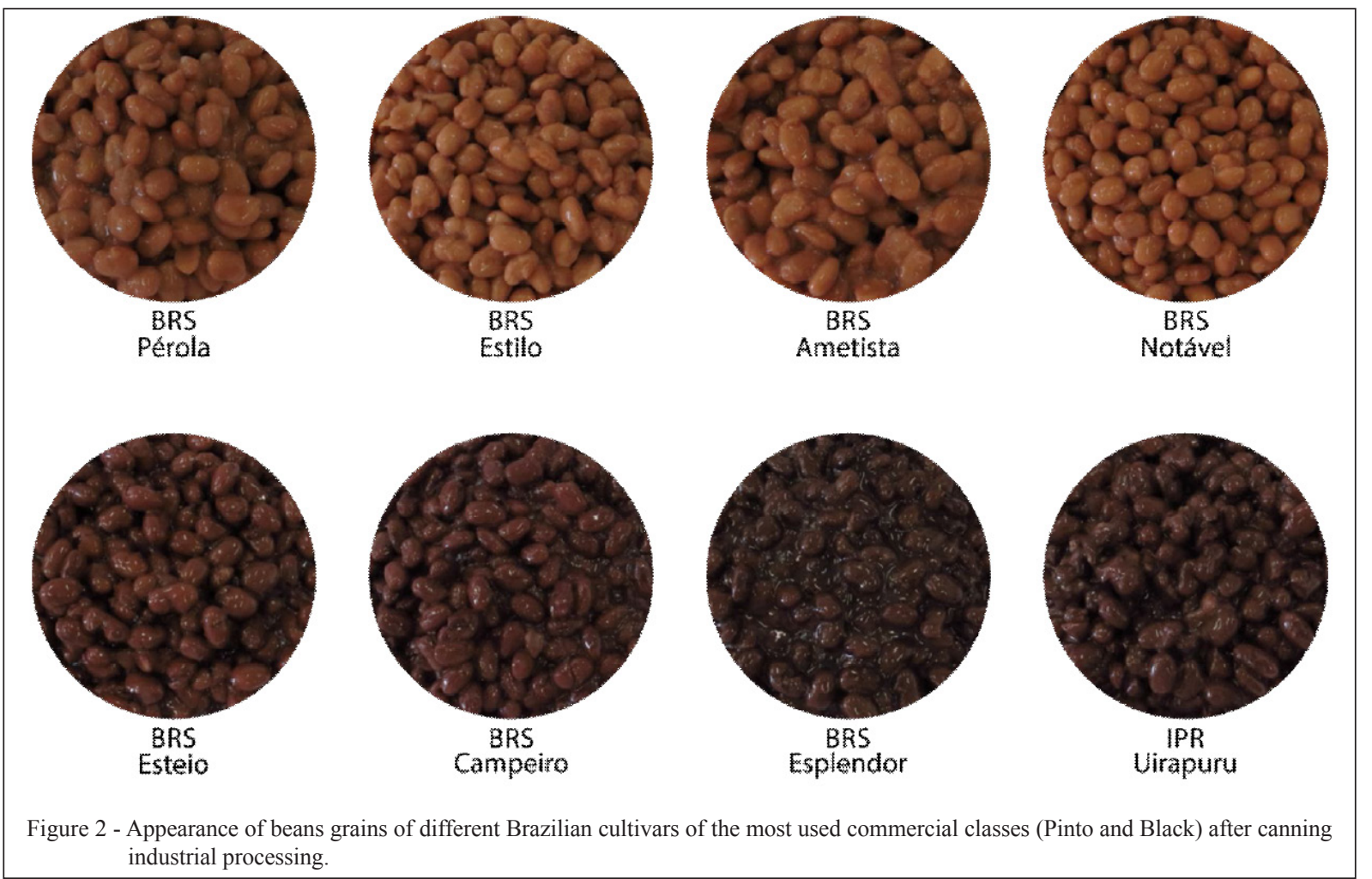

pigment, darkening reactions, ascorbic acid oxidation, acidification, and heavy metals contamination (GUZEL \& SAYAR, 2012). To determine color, a colorimeter device is used in the Hunter Lab color space by reading the luminosity color coordinates (L), red-green color component (a), and yellow-blue color component (b). Other color spaces may also be used such as CIELAB by obtaining $\mathrm{L}^{*}, \mathrm{a}^{*}$ and $\mathrm{b}^{*}$ values, and calculating the chromaticity $(\mathrm{C})$ and coloration angle $\left(\mathrm{H}^{*}\right)$ color parameters. Two samples of each package are taken, with two readings for each sample, thereby standardizing surface irregularities of the grains (HOSFIELD et al., 1984; MERWE et al., 2006a; WHITE \& HOWARD, 2013).

The soluble-solids content is also determined in the processed beans broth by direct reading of the ${ }^{\circ} \mathrm{Brix}$ level with either a portable device or a workbench device known as a refractometer. A final important aspect is the broth consistency, which is assessed using a viscometer (WHITE \& HOWARD, 2013).

\section{CONCLUSION}

The discussion in this study analyzed the singularities of the industrial processing of beans by describing details of the process and the final product quality characteristics. Processing adds value to beans, and contributes to the increased inclusion of the grain in the diet of the consumers who look for quality products that are easy to prepare. Consequently, this increase in consumption would lead to greater production in both high technology systems and familial production units, which are currently responsible for most of the Brazilian beans production. Lastly, these continuing efforts with the Brazilian beans production chain should increase the demand for industrial processing targeted toward external markets and future product exports.

\section{ACKNOWLEDGEMENTS}

The authors thank the Coordenação de Aperfeiçoamento de Pessoal de Nível Superior (CAPES) for its financial support through a scholarship (PDSE Processo: BEX 3175/14-6).

\section{SOURCES AND MANUFACTURES}

On-site personal communication done the author at the Quero Canning Industry with the person responsible for the quality sector on December $6^{\text {th }}, 2012$ in the city of NerópolisGO, and also at the Oderich Canning Industry in the city of São Sebastião do Cai-RS, on November $5^{\text {th }}, 2013$. 


\section{REFERENCES}

ABU-GHANNAM, N.; MCKENNA, B. Hydration kinetics of red kidney beans (Phaseolus vulgaris L.). Journal of Food Science, v.62, n.3, p.520-523, 1997. Available from: <http://onlinelibrary. wiley.com/doi/10.1111/j.1365-2621.1997.tb04420.x/pdf>. Accessed: May 12, 2015. doi: 10.1111/j.1365-2621.1997.tb04420.

ALMEIDA, A.J.B. et al. Perfil dos consumidores de feijão na cidade de Cascavel - Paraná. In: CONGRESO LATINOAMERICANO Y DEL CARIBE DE INGENIERÍAAGRÍCOLA, 10; CONGRESSO BRASILEIRO DE ENGENHARIA AGRÍCOLA CLIA/CONBEA 41., 2012, Londrina, PR, Brasil Anais... Londrina: CLIA/ CONBEA, 2012. 1-4.

BALASUBRAMANIAN, P. et al. Genotype and environment effect on caning quality of dry bean grown in Saskatchwan. Canadian Journal of plant science, v.79, n.1, p.335-342, 1999. Available from: <http://pubs.aic.ca/doi/pdfplus/10.4141/P98107>. Accessed: May 12, 2015. doi: 10.4141/P98-107.

BALASUBRAMANIAN, P. et al. A modified laboratory canning protocol for quality evaluation of dry bean (Phaseolus vulgaris L.). Journal of the Science of Food and Agriculture, v.80, p.732-738, 2000. Available from: $<$ http://onlinelibrary.wiley.com/ doi/10.1002/(SICI)1097-0010(20000501)80:6\%3C732::AIDJSFA606\%3E3.0.CO;2-X/epdf>. Accessed: May 12, 2015. doi: $10.1002 /(\mathrm{SICI}) 1097-0010(20000501) 80: 6<732$ :AIDJSFA606>3.0.CO;2-X.

BASSINELLO, P.Z. Qualidade na escolha de variedades de feijão para o mercado consumidor. Atualidades em micotoxinas e armazenagem qualitativas de grãos 11. Florianópolis: Imprensa Universitária, 2008. 586p.

BUT, M.S.; SULTAN, M.T. Nutricional profile of vegetables an its significance to human healt. In: SINHA, N.K. Handbook of vegetables \& vegetable processing. Ames: Wiley \& Sons, 2011. p.243-258.

CICHY, K.A. et al. QTL analysis of canning quality and color retention in black beans (Phaseolus vulgaris L.). Molecular Breeding, v.33, n.1, p.139-154, 2014. Available from: <http://link. springer.com/article/10.1007/s11032-013-9940-y>. Accessed: Jul. 12, 2016. doi: 10.1007/s11032-013-9940-y.

FELLOWS, P.J. Tecnologia do processamento de alimentos Princípios e prática. Porto Alegre: Artmed, 2006. 602p.

GUZEL, D.; SAYAR, S. Effect of cooking methods on selected physicochemical and nutricional properties of barlotto bean, chickpea, faba bean, and white kidney bean. Journal of Food Science and Technology, v.49, n.1, p.89-95, 2012. Available from: <http://www.ncbi.nlm.nih.gov/pmc/articles/PMC3550881/ pdf/13197_2011_Article_260.pdf>. Accessed: May 12, 2015. doi: 10.1007/s $13197-011-0260-0$.

HOSFIELD, G.L. et al. A factor analysis of yeld and sensory and physico-chemical data from tests used to measure culinary quality in dry edible beans. Canadian Journal of Plant Science, v.64, n.1, p.285-293, 1984. Available from: <http://pubs.aic.ca/ doi/pdfplus/10.4141/cjps84-042>. Accessed: May 12, 2015. doi: 10.4141/cjps84-042.

KELLY, J.D.; CICHY, K.A. Dry bean breeding and production technologies. In: SIDDIQ, M.; UEBERSAX, M.A. Dry beans and pulses: production, processing and nutrition. Ames: Jonh Wiley \& Sons, 2013b. p.23-54.

LIMA, R.A. et al. Embalagem a vácuo: efeito no escurecimento e endurecimento do feijão durante o armazenamento. Ciência Rural, v.44, n.9, p.1664-1670, 2014. Available from: <http://www.scielo. br/pdf/cr/v44n9/0103-8478-cr-44-09-01664.pdf>. Accessed: May 12, 2015. doi: 10.1590/0103-8478cr20120832.

MATELLA, N.J. et al. Hidration, blanching and thermal processing of dry beans. In: SIDDIQ, M.; UEBERSAX, M.A. Dry beans and pulses: production, processing and nutrition. Ames: Jonh Wiley \& Sons, 2013. p.129-154.

MERWE, D.V.D. et al. Evaluation and standardization of smallscale canning methods for small white beans (Phaseolus vulgaris L.) canned in tomato sauce. Journal of the Science of Food and Agriculture, v.86, p.1115-1124, 2006. Available from: <http:// onlinelibrary.wiley.com/doi/10.1002/jsfa.2476/epdf>. Accessed: May 12, 2015. doi: 10.1002/jsfa.2476.

MISHRA, D.K.; SINHA, N.K. Principles of vegetable canning. In: SINHA, N.K. Handbook of vegetables \& vegetable processing. Ames: Wiley \& Sons, 2011. p.243-258.

OSORIO-DIAZ, P. et al. In vitro digestability and resistant starch content of some industrialized commercial beans (Phaseolus vulgaris). Food Chemistry, n.78, p.333-337, 2002. Available from: <http://www.sciencedirect.com/science/article/pii/ S0308814602001176>. Accessed: May 12, 2015. doi: 10.1016/ S0308-8146(02)00117-6.

PAN, Z. et al. Development of impact acoustic detection and density separations methods for production of high quality processed beans. Journal of Food Engineering, v.97, n.1, p.292-300, 2010. Available from: $<$ http://www.sciencedirect.com/science/article/pii/ S0260877409005147>. Accessed May 12, 2015. doi: 10.1016/j. jfoodeng.2009.10.016.

PEDROSA, M.M. et al. Effects of industrial canning on the proximate composition, bioactive compounds contents and nutritional profile of two Spanish common dry beans (Phaseolus vulgaris L.). Food Chemistry, v.166, n.1, p.68-75, 2014. Available from: $<$ http://www.sciencedirect.com/science/article/pii/ S0308814614008887>. Accessed: May 12, 2015.

POSA-MACALINCAG, M. et al. Quantitative Trait Loci (QTL) analysis of canning quality traits in kidney bean (Phaseolus vulgaris L). Journal of the American Society for Horticulture Science, v.127, n.4, p.608-615, 2002. Available from: <http:// journal.ashspublications.org/content/127/4/608.full.pdf + html $>$. Accessed: July 12, 2016.

RONDINI, E.A. et al. Nutrition and human health benefits of dry beans and pulses. In: SIDDIQ, M.; UEBERSAX, M.A. Dry beans and pulses: production, processing and nutrition. Ames: Jonh Wiley \& Sons, 2013. p.359-377.

SIDDIQ, M. et al. Dry beans: production, processing, and nutrition. In: SINHA, N.K. Handbook of vegetables \& vegetable processing. Ames: Wiley \& Sons, 2011. p.545-564.

SLUPSKI, J. Effect of freezing and canning on the thiamine and riboflavin content in immature seeds of five cultivars of common bean (Phaseolus vulgaris L.). International Journal of Refrigeration, v.35, n.1, p.890-896, 2012. Available from: <http:// 
www.sciencedirect.com/science/article/pii/S0140700711003021>. Accessed: May 12, 2015. doi: 10.1016/j.ijrefrig.2011.12.001.

SPOTO, M.H.F.; MIGUEL, A.C.A. Processamento mínimo e congelamento. In: OETTERER, M. et al. Fundamentos de ciência e tecnologia de alimentos. Barueri Manole, 2010. p.453-479.

UEBERSAX, M.A.; SIDDIQ, M. Postharvest storage quality, packaging and distribuition of dry beans. In: SIDDIQ, M.; UEBERSAX, M.A. Dry beans and pulses: production, processing and nutrition. Ames: Jonh Wiley \& Sons, 2013. p.75-100.

UEBERSAX, M.A. Dry edible beans: indigenous staple and healthy cuisine. Forum on Public Policy. Urbana, A Journal of the Oxford round table. 2006. Available from: $<$ http://www. forumonpublicpolicy.com/archive06/uebersax.pdf $>$. Accessed: Feb. 27, 2015

WALTERS, K.J. et al. Navy bean canning quality: correlations, heritability estimates, and randomly amplified polymorphic DNA markers associated with component traits. Journal of the American Society for Horticulture Science, v.122, n.3, p.338343, 1997. Available from: <http://journal.ashspublications.org/ content/122/3/338.full.pdf + html $>$. Accessed: May 02, 2015.

WANG, C.R.; CHANG, S.K.C. Effect of selected canning methods on trypsin inhibitor activity, sterilization value, and firmness of canned navy beans. Journal Agricultural and Food Chemistry, v.36, p.1015-1018, 1988. Available from: <http://pubs.acs.org/ doi/abs/10.1021/jf00083a028>. Accessed: May 12, 2015. doi: 10.1021/jf00083a028.

WHITE, B.; HOWARD, L.R. Canned whole dry beans and bean products. In: SIDDIQ, M.; UEBERSAX, M.A. Dry beans and pulses: production, processing and nutrition. Ames: Jonh Wiley \& Sons, 2013. p.155-183.

YUCEL, U. et al. Evaluation of high pressure pretreatment for enhancing the drying rates of carrot, apple, and green bean. Journal of Food Engineering, v. 98, n.1, p.266-272, 2010. Available from: $<$ http://www.sciencedirect.com/science/article/pii/ S0260877410000087>. Accessed: May 12, 2015. doi: 10.1016/j. jfoodeng.2010.01.006.

ZANOVEC, M. et al. Comparison of nutrient density and nutrientto-cost between cooked and canned beans. Food and Nutrition Sciences, v.2, p.66-73, 2011. Available from: $<$ http://www.scirp. org/journal/PaperInformation.aspx?PaperID $=4521>$. Accessed: May 12, 2015. doi: 10.4236/fns.2011.22009.

ZAMINDAR, N. et al. Effect of line, soaking and cooking time on water absorption, texture and splitting of red kidney beans. Journal of Food Science and Technology, v.50, n.1, p.08114, 2013. Available from: <http://www.ncbi.nlm.nih.gov/ pubmed/24425894>. Accessed: May 12, 2015. doi: 10.1007/ s13197-011-0234-20.182. 